\title{
Larry Prochner \\ A history of early childhood education in Canada, Australia, and New Zealand.
}

Vancouver: UBC Press, 2009. 339 pp.

\section{Kevin J. Brehony}

Roehampton University

In recent decades there has been a growth in histories of the arrangements made for the education and care of children in their early years. Larry Prochner's book is a welcome addition to this literature that in various ways, as he acknowledges, is related to the contemporary political debate over the nature of early childhood education and to the recent rapid expansion of its provision. Most of that literature has focused on early childhood education in a particular nation state. Like this volume, some of it has been comparative in approach but Prochner's differs in that he drew a purposive sample for comparison, a subset of British settler colonies, as indicated in the book's title. However, this is something of a misnomer as his discussion of early childhood education overflows the selected nation containers and mention is made, for example, of infant schools in South Africa, Samoa and modern Tahiti.

Prochner's account, notably in Chapters two and five, is one of the cultural flows that accompanied human migration and transfers of capital and commodities. In World System Theory terms, the flows, initially at least, were overwhelmingly from the core to the periphery. Thus the infant school travelled from Britain and the Froebelian kindergarten, the focus of Chapters five to nine, from Germany by way of England and the United-States to the selected colonies.

No rationale is given for the selection of Canada, Australia and New Zealand termed by Prochner, the "case study countries." What the "case" consists of is not discussed either and it is left to the reader to decide whether, the case studied is of early childhood care and education or its development in each of the countries chosen. The three nations were once referred to egregiously as being part of the "white dominions" in which, once the resistance of their indigenous populations had been broken, their governments enjoyed a measure of political autonomy unknown in 
Britain's other colonies. Nevertheless, instead of national variation in the early childhood education provided, Prochner found a high degree of similarity as pedagogic developments in the core countries were reproduced in the peripheral "case study countries" and this despite much of it, at the outset, being the result of private initiative. Missionaries provided much of that, in the form of colonial infant schools, for settler and indigenous children alike. This occurred initially in segregated institutions but subsequently, assimilation of the indigenous populations became a principal aim.

Among this books many strengths is a discussion of long and short-term child-care which took a variety of forms ranging from the hospital and workhouse to crèches and day nurseries. While Prochner's account of child-care is subsidiary to his main theme, which is the diffusion of the kindergarten, he breaks with the usual practice of historians of early childhood education of virtually ignoring child-care as if it could never be educative.

Following this prelude on child-care, a skillful sketch of the kindergarten is provided together with its dispersal from its point of origin in Bad Blankenburg in the German state of Thuringia to many countries including those highlighted here. Beginning as a predominantly middle-class institution, Prochner traces the rise of the free kindergarten movement in the United-States and demonstrates how it was directed at the children of immigrants drawn to the newly emerging urban centres, amid growing anxieties about crime, anarchy and socialism. The pattern was repeated in Australia and New Zealand but not Canada where kindergartens were provided in the public school system during the early 1880s. Alongside the growth of kindergartens providing "redemption and basic education" (170) for the children of the labouring poor, training colleges such as the Sydney Kindergarten Teachers College were established to provide teachers for them.

Three chapters provide detailed descriptive accounts of the Winnipeg Free Kindergarten Association, the Kindergarten Union of New South Wales, and the Wellington Free Kindergarten Association respectively. Among the themes common to all three were the relation to the state and to their public education systems; the efficacy of the kindergarten and the growth of what have been variously termed liberal, progressive or revisionist pedagogies emanating from the United States - and perhaps indexing its emergence as a hegemonic power in the world system; and the ingress of Montessori's ideas and practices into the field.

The final chapter, while valuable in many respects, does not provide the conclusion its title promises and it ends rather abruptly. What does appear in this chapter, however, is a revisiting of an observation made earlier that the kindergarten's innovative pedagogy and an attention to children's development tended to be supplanted by other concerns such as the protection of children and the struggle for survival which often led to the adoption of primary school methods. All this was at the expense of Froebel's mystical philosophy; a case illustrative perhaps of Max Weber's theory of rationalization but Prochner, having chronicled and adumbrated the kindergarten movement's many contradictions, does not offer much by way of theoretical explanation for the transitions he observes from innovation to what looks rather like Weber's notion of routinisation. 
Prochner's explanations for the rise of the kindergarten and the decline of the infant school are also a little attenuated. The appearance of "new maternalist thinking" (84) is cited but this seems to rely overmuch on ideas as the motor of change. Later, this explanation is qualified by the observation that at the moment of the kindergarten's inception, upper-class women "embraced Froebel's notion of maternalism" (166) but no assessment is offered of why this may have served their interests as women in a male-dominated world and the impact that had on the kindergarten's subsequent history.

Finally, while due attention is given to the context in which early childhood education developed in the selected societies, with emphasis being given to the impact on families and childhood of the twin processes of industrialization and urbanization, the book contains little about the demand of mothers for child-care and education. This phenomenon is more recent than the period covered by the book, which ends around the Second World War, but Prochner does mention the popularity among many English working-class parents during the nineteenth century of the dame schools, essentially private working class schools. These were only one of a number of preferred private arrangements for child-care that also encompassed care of children by older siblings and relatives. This was one side of a coin the other of which was suspicion of, and resistance to, the philanthropic efforts of the free kindergarteners. Whether, provision was public or private in the three countries, the impression given in this account is of the imposition of early childhood education on the urban poor and the indigenous populations. Protection, assimilation, social control and childsaving rather than social reform were the order of the day.

There is so much more to this important book than can be discussed as its breadth of focus and depth of scholarship is remarkable. It will be of interest not only to historians of education but also to historians of childhood, social policy, the kindergarten movement and of colonial relations. Prochner skillfully holds together the general and the particular across a large expanse of time and space and his very readable account is highly recommended. 